\title{
Evaluation of N-Terminal Pro Brain Natriuretic Peptide as a biomarker for clinical severity of heart failure in pediatric population
}

\author{
Mohammad Nagib Abou Al Fotouh ${ }^{1}$, Ashgan Abdallah Alghobashy, \\ Yousry El Sayed Abou Al Magd ${ }^{2}$, Nermin Raafat ${ }^{2}$ \\ and Hanan Mohammed Hassan ${ }^{1}$. \\ ${ }^{1}$ Pediatric Department, Faculty of Medicine, Zagazig University, Egypt \\ ${ }^{2}$ Medical Biochemistry Department, Faculty of Medicine, Zagazig University, Egypt
}

Corresponding Author Hanan Mohammed Hassan

Mobile: $+201224575613$

E mail: hananmohammed30@ yahoo.com

Key words: Heart failure, $N$-terminal pro$B N P$, biomarker, severity, pediatric
Background and study aim: Brain Natriuretic Peptide (BNP) and N-Terminal pro-Brain Natriuretic Peptide (NT-pro $\mathrm{BNP}$ ) are frequently used in the diagnosis of congestive heart failure (CHF), especially for distinguishing between patients with dyspnea of cardiac and pulmonary origin. The present work aimed at evaluating $\mathrm{N}$ Terminal pro-Brain Natriuretic Peptide (NT-proBNP) as a biomarker for diagnosis of congestive heart failure (CHF) in pediatrics and as well as its severity and hence, helping early diagnosis of CHF in absence of rapid echocardiographic examination.

Subjects and Methods: The patients group (group I) consisted of 45 children (24 males and 21 females) aging between 45 days and 12 years. All having the inclusion criterion of CHF. They were subclassified into: group I-1 including 15 patients having dilated cardiomyopathy (DCM), group I-2 including 15 patients having congenital heart disease (CHD) and group I-3 including 15 patients that have developed $\mathrm{CHF}$ due to non-cardiac causes. The control group was formed of 15 healthy children (group II) matched in age and gender with the patients groups. All children were subjected to full history taking, physical examination, classification of clinical severity of $\mathrm{CHF}$ cases according to Modified Ross Score, imaging and laboratory investigations including serum level of NT-proBNP.

Results: The study revealed that serum NT-proBNP showed a highly statistically significant increase in $\mathrm{CHF}$ cases three groups (I-1, I-2 and I-3) in comparison to the control group (group II) $(\mathrm{P}<0.001)$. NT-proBNP level showed highly statistically significant positive correlation with CHF class of clinical severity $(\mathrm{P}<0.001)$. Regarding echocardiographic parameters NT-proBNP showed a highly significant positive correlation with left ventricular end diastolic dimensions (LVEDD) and left ventricular end systolic dimensions (LVESD), and a highly significant negative correlation with left ventricular (LV) ejection fraction (EF), fractional shortening (FS) and mitral valve E/A ratio. At cutoff level of 1500 $\mathrm{pg} / \mathrm{ml}$, the sensitivity of NT-proBNP as a diagnostic biomarker in children with $\mathrm{CHF}$ was $98 \%$ and the specificity was $100 \%$.

Conclusion: NT-proBNP is significantly statistically correlated with clinical severity of $\mathrm{CHF}$ and echocardiographic parameters of $\mathrm{CHF}$ cases of different causes .We highly recommend a long-term study on the value of the level of NT-proBNP as a prognostic risk parameter.

\section{INTRODUCTION}

$\mathrm{CHF}$ is a clinical syndrome where the heart is unable to provide the output required to meet the metabolic demands of the body; however, the causes and mechanisms of CHF are significantly different between adults and children [1]. There is no single diagnostic test for CHF because it is largely a clinical diagnosis based on a 
careful history and physical examination [2]. In early stages of $\mathrm{CHF}$, various compensatory mechanisms are evoked to maintain normal metabolic function [1]. The clinical syndrome of $\mathrm{CHF}$ is a final common pathway of most forms of cardiovascular disease [3]. Several studies have reported the prevalence of CHF to vary between 3\% and 9\% [4-6]. Thus, it is a pediatric emergency that must be anticipated and excluded in every acutely ill child [6]. CHF has multiple causes: predominant among these in developed countries are the primary cardiomyopathies, which account for $60 \%$ of children requiring a cardiac transplant, and the congenital heart diseases [7]. In addition, certain systemic processes such as inflammatory diseases, metabolic disorders, endocrine derangements, and kidney disease result in an unknown number of cases [8].

B-type natriuretic peptide (BNP) is a member of a four natriuretic peptide family that shares a common 17-peptide ring structure. The $\mathrm{N}$-terminal fragment (NT-pro-BNP) is biologically inert, but both are secreted in the plasma in equimolar quantities and both have been evaluated for use in the management of CHF [9]. BNP stimulates natriuresis and vasodilation with consequent afterload reduction, inhibits renin- angiotensinaldosterone release and sympathetic nervous activity, and reduces fibrosis. BNP and NT-proBNP are frequently used in the diagnosis of CHF and distinguishing between patients with dyspnea of cardiac or pulmonary origin. 'Normal' values of these peptides vary depending on the type of test used. The performance characteristics of these tests vary depending on the patients on whom they are used and the manufacturer. For this reason, the determination of reference values for this peptide represents such a challenge [9].

\section{SUBJECTS AND METHODS}

This case control study was carried out at Pediatric Cardiology Unit, Pediatric Intensive Care Unit and Medical Biochemistry Department in Zagazig University Hospitals during the period from March 2012 to September 2014.

\section{Subjects :}

The study covered 60 subjects that will be divided into the following groups:

\section{Group I : (CHF patients):}

Forty five patients in pediatric age groups ranging between 1.5 months and 12 years, 21 $(46.7 \%)$ males and $24(53.3 \%)$ females. All the patients in group I have the inclusion criterion of having clinical CHF signs and symptoms, and they will be subdivided into 3 groups:

Group I-1: Fifteen patients having DCM.

Group I-2: Fifteen patients having CHD : 7 cases of common atrio-ventricular canal (CAVC) (47\%), 3 cases of combined atrial septal defect (ASD) and ventricular septal defect (VSD) (20\%), 2 cases of combined ASD, VSD and pulmonary stenosis (PS) (13\%), one case VSD (6.7\%), one case of double inlet left ventricle (DILV) ( 6.7\%) and one case of tricuspid atresia $(6.7 \%)$.

Group I-3: Fifteen patients that developed CHF secondary to non cardiac causes involving: 6 cases of severe pneumonia (40\%), 4 cases of acute severe asthma (27\%), one case of severe bronchiolitis $(6.7 \%)$, one case of severe bronchopneumonia (6.7\%), one case of Acute Respiratory distress Syndrome(ARDS) (6.7\%), one case of right lung collapse $(6.7 \%)$ and one case of anemic heart failure on top of acute severe hemolysis $(6.7 \%)$.

\section{Exclusion criteria including:}

1- Recent cardiopulmonary surgery.

2- Current hemodialysis.

\section{Group II (control group):}

Fifteen healthy individual as a control group, the subjects of this group are matched in age and gender to the patients groups.

All children in this study were subjected to complete history taking, general examination including vital signs and anthropometric measures, cardiac examination, chest examination, abdominal examination and clinical assessment of CHF with grading of severity according to Modified Ross Score.

X-ray chest and heart and standard 12 lead Electrocardiography (ECG) were performed. Echocardiographic study was performed in all patients using Ultrasound Machine, Vivid7 (GE medical system, Horten, Norway). Echocardiographic examination included LVEDD, LVESD, and LV systolic function in the form of left ventricular EF and FS using two-dimensional echocardiography and M-mode echocardiography. Also mitral valve E/A ratio was performed by continuous wave (CW) Doppler. By echocardiography, $\mathrm{EF} \%<50 \%$ was systolic heart failure and mitral valve $\mathrm{E} / \mathrm{A}$ ratio $<1$ was diastolic heart failure ${ }^{(10)}$.

Blood for NT-proBNP assay was taken from peripheral venous puncture $(3 \mathrm{ml})$ and collected in serum separator tubes (SST) within 3 hours of 
the echocardiography and allowed samples to clot for 30 minutes before centrifugation for 15 minutes. Serum was removed and stored at $-20^{\circ} \mathrm{C}$ until the time of analysis. All reagents were brought to room temperature before use. NTproBNP was analyzed using a research NTproBNP ELISA Kit (EIAAB and USCN Life Company, China).

\section{Statistical analysis:}

All data were collected, tabulated and statistically analyzed using Statistical Package for the Social Sciences (SPSS version 18). Quantitative data were expressed as the mean \pm SD \& median (range). Continuous data were checked for normality by using Shapiro Walk test. Independent Student t-test was used to compare two groups of normally distributed data. Mann-Whitney test was used to compare two groups of non normally distributed data. ANOVA (Analysis of variance) was used to test the difference about mean values of parameters of normally distributed data among the groups of study. Kruskal-Wallis test was used to compare more than two groups of non normally distributed data. Spearman's coefficient was calculated to assess relationship between study parameters, (+) sign indicate direct correlation and (-) sign indicate inverse correlation, also values near to 1 indicate strong correlation \& values near 0 indicate weak correlation. All tests were two sided, $\mathrm{P}<0.05$ was considered statistically significant ( $\mathrm{S}$ ), $\mathrm{P}<0.001$ was considered highly statistically significant (HS), and $\mathrm{P} \geq 0.05$ was considered non statistically significant (NS).

\section{RESULTS}

Group I involved our CHF cases who showed different stages of CHF either acute or chronic or resolving CHF. Group II consisted of 15 healthy control subjects matched in age and sex with the groups of CHF cases. There are statistically non significant differences in our study between the groups of cases and the group of control regarding age, gender, body weight and length. There are statistically non-significant difference between the three groups of cases regarding symptoms and signs (Hepatomegaly, dyspnea, edema, orthopnea and cyanosis) . According to clinical severity, CHF cases (45cases of group I) were classified according to Modified Ross Score into : Five cases $(11.1 \%)$ as Ross IA (mild CHF), 11 cases $(24.4 \%)$ as Ross IB (moderate CHF) and 29 cases (64.4\%) as Ross IC (severe CHF) . There is statistically non-significant difference between the three groups of CHF cases (Group I-1, I-2 and I-3) regarding distribution of cases clinical severity of CHF according to Modified Ross Score (Table 1).

Table (1): Comparison of Modified Ross Score among the cases groups

\begin{tabular}{|c|c|c|c|c|c|c|c|c|}
\hline \multirow[t]{2}{*}{ Variable } & \multicolumn{2}{|c|}{$\begin{array}{c}\text { GroupI-1 } \\
\text { (DCM) } \\
(\mathbf{n}=15)\end{array}$} & \multicolumn{2}{|c|}{$\begin{array}{c}\text { Group I-2 } \\
\text { (CHD) } \\
(\mathbf{n}=15)\end{array}$} & \multicolumn{2}{|c|}{$\begin{array}{c}\text { Group I-3 } \\
\text { (NCCHF) } \\
(n=15)\end{array}$} & \multirow[t]{2}{*}{$\chi^{2}$} & \multirow[t]{2}{*}{$\mathbf{P}$} \\
\hline & $\mathbf{N}$ & $\%$ & $\mathbf{N}$ & $\%$ & $\mathbf{N}$ & $\%$ & & \\
\hline $\begin{array}{l}\text { Modified Ross: } \\
\text { Ross IA } \\
\text { Ross IB } \\
\text { Ross IC }\end{array}$ & $\begin{array}{c}0 \\
4 \\
11\end{array}$ & $\begin{array}{c}0 \\
27 \\
73\end{array}$ & $\begin{array}{c}1 \\
2 \\
12\end{array}$ & $\begin{array}{c}7 \\
13 \\
80\end{array}$ & $\begin{array}{l}4 \\
5 \\
6\end{array}$ & $\begin{array}{l}27 \\
33 \\
40\end{array}$ & 8.61 & $\begin{array}{c}0.072 \\
\text { NS }\end{array}$ \\
\hline
\end{tabular}

DCM= Dilated cardiomyopathy

$\mathrm{CHD}=$ Congenital heart diseases

$\mathrm{NCCHF}=$ non cardiac causes of $\mathrm{CHF}$

$\chi^{2}=$ Chi-square test

NS $=$ Non Significant

Some echocardiographic diameters left ventricular $\mathrm{EF}, \mathrm{FS}$ and mitral valve E/A ratio) showed statistically highly significant decrease in the three groups of cases (groups I-1, I-2 and I-3) compared to the control group (group II) with $\mathrm{p}$ value < 0.001, while LVEDD and LVESD showed statistically highly significant increase in the three groups of cases (groups I-1, I-2 and I-3) compared to the control group (group II) with $\mathrm{p}$ value $<0.001$ (Table 2, Fig. 1), but there is statistically non significant difference between groups of cases (groups I-1, I-2 and I-3) regarding the echocardiographic parameters (EF, FS, LVEDD, LVESD and mitral valve E/A). 
Table (2): Comparison of ECHO findings of the studied groups cases and control

\begin{tabular}{|l|c|c|c|c|c|c|}
\hline \multicolumn{1}{|c|}{ Variable } & $\begin{array}{c}\text { Group I-1 } \\
(\mathbf{D C M}) \\
(\mathbf{n = 1 5})\end{array}$ & $\begin{array}{c}\text { Group I -2 } \\
(\mathbf{C H D}) \\
(\mathbf{n = 1 5})\end{array}$ & $\begin{array}{c}\text { Group I-3 } \\
(\mathbf{N C C H F}) \\
(\mathbf{n = 1 5 )}\end{array}$ & $\begin{array}{c}\text { Group II } \\
(\mathbf{C o n t r o l}) \\
(\mathbf{n = 1 5})\end{array}$ & F & $\mathbf{p}$ \\
\hline $\begin{array}{l}\text { EF (\%): } \\
\text { Mean } \pm \text { SD }\end{array}$ & $40.27 \pm 5.43$ & $45.2 \pm 10.05$ & $44.8 \pm 9.6$ & $71.33 \pm 4.59$ & 49.16 & $<0.001 \mathrm{HS}$ \\
\hline $\begin{array}{l}\text { FS (\%): } \\
\text { Mean } \pm \text { SD }\end{array}$ & $20.2 \pm 4.14$ & $23.27 \pm 5.08$ & $23 \pm 6.07$ & $39.47 \pm 4.24$ & 47.15 & $<0.001 \mathrm{HS}$ \\
\hline $\begin{array}{l}\text { LVEDD(mm) } \\
\text { Mean } \pm \text { SD }\end{array}$ & $46.33 \pm 4.25$ & $41.80 \pm 8.86$ & $40.93 \pm 9.37$ & $32.33 \pm 6.38$ & 9.11 & $<0.001 \mathrm{HS}$ \\
\hline $\begin{array}{l}\text { LVESD(mm) } \\
\text { Mean } \pm \text { SD }\end{array}$ & $35.27 \pm 5.09$ & $31.73 \pm 7.9$ & $30.6 \pm 8.19$ & $20.0 \pm 4.7$ & 14.57 & $<0.001 \mathrm{HS}$ \\
\hline $\begin{array}{l}\text { E/A: } \\
\text { Mean } \pm \text { SD }\end{array}$ & $1.04 \pm 0.25$ & $0.97 \pm 0.11$ & $1.08 \pm 0.18$ & $1.54 \pm 0.20$ & 26.8 & $<0.001 \mathrm{HS}$ \\
\hline
\end{tabular}

$\mathrm{EF}=$ Ejection fraction

HS=High Significance

FS = Fractional shortening

LVESD = Left ventricular end systolic dimensions

LVEDD $=$ Left ventricular end diastolic dimensions

$\mathrm{E} / \mathrm{A}$ ratio $=$ Mitral valve E/A ratio

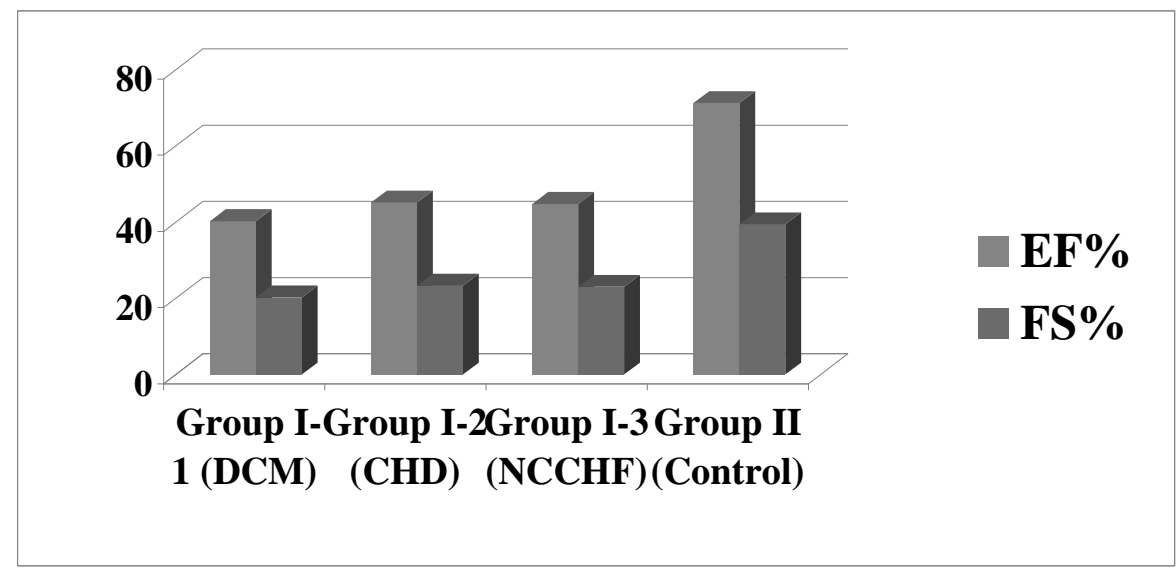

Figure (1): Comparison between groups of CHF cases and control group as regard EF and FS.

The serum level of NT-proBNP showed statistically highly significant statistical increase in groups of cases (I-1, I-2 and I-3) compared to the control group (group II) with $\mathrm{p}$ value <
0.001.(Table 3, Fig. 2), but there is statistically non significant difference between the three groups of cases regarding the serum level of NTproBNP with $\mathrm{p}$ value $>0.05$ (Table 4).

Table (3): Comparison of NT-proBNP level of the studied groups (cases and control)

\begin{tabular}{|c|c|c|c|c|c|c|}
\hline Variable & $\begin{array}{c}\text { Group I-1 } \\
(\mathbf{D C M}) \\
(\mathbf{n = 1 5})\end{array}$ & $\begin{array}{c}\text { Group I-2 } \\
(\mathbf{C H D}) \\
(\mathbf{n = 1 5})\end{array}$ & $\begin{array}{c}\text { Group I-3 } \\
(\mathbf{N C C H F}) \\
(\mathbf{n = 1 5})\end{array}$ & $\begin{array}{c}\text { Group II } \\
(\text { Control) } \\
(\mathbf{n = 1 5})\end{array}$ & $\mathbf{K w}$ & $\mathbf{p}$ \\
\hline $\begin{array}{c}\text { NT- ProBNP }(\mathbf{p g} / \mathbf{m l}) \\
\begin{array}{l}\text { Median } \\
\text { Range }\end{array}\end{array}$ & 6200 & 6300 & 4800 & 179 & & $<0.001$ \\
& $4800-10800$ & $530-6800$ & $1900-6800$ & $89-1100$ & 36.18 & HS \\
\hline
\end{tabular}

$\mathrm{KW}=$ Kruskal Wallis test

HS= Highly Significant 
Table (4): Comparison of NT- ProBNP level of cases groups

\begin{tabular}{|l|c|c|c|c|c|}
\hline Variable & $\begin{array}{c}\text { Group I-1 } \\
(\mathbf{D C M}) \\
(\mathbf{n = 1 5}\end{array}$ & $\begin{array}{c}\text { Group I-2 } \\
(\mathbf{C H D}) \\
(\mathbf{n = 1 5})\end{array}$ & $\begin{array}{c}\text { Group I-3 } \\
(\mathbf{N C C H F}) \\
(\mathbf{n = 1 5})\end{array}$ & $\mathbf{K W}$ & $\mathbf{p}$ \\
\hline $\begin{array}{l}\text { NT- ProBNP }(\mathbf{p g} / \mathbf{m l}) \\
\text { Median } \\
\text { Range }\end{array}$ & $\begin{array}{c}6200 \\
4800-10800\end{array}$ & $530-6800$ & $\begin{array}{c}4800 \\
1900-6800\end{array}$ & 5.59 & $\begin{array}{c}0.06 \\
\text { NS }\end{array}$ \\
\hline
\end{tabular}

KW= Kruskal Wallis test

NS $=$ Non Significant

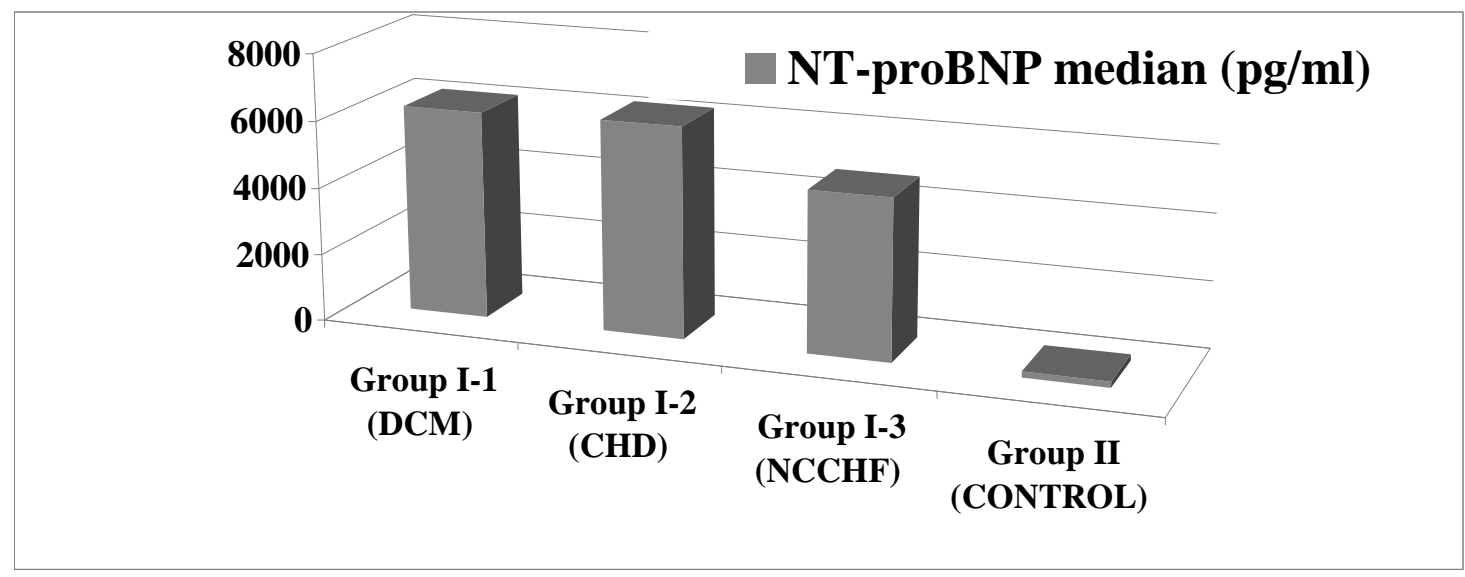

Figure (2): Comparison between groups of CHF cases and control group as regard the serum level of NT-proBNP

There is statistically highly significant difference between the three classes of Modified Ross
Score in CHF cases regarding the serum level of NT-proBNP (Table5).

Table (5): Relation between NT-ProBNP level of Group I (45 cases of CHF) and Modified Ross scoring

\begin{tabular}{|l|c|c|c|c|c|}
\hline \multicolumn{1}{|c|}{ Variable } & $\begin{array}{c}\text { Ross IA } \\
(\mathbf{n = 5})\end{array}$ & $\begin{array}{c}\text { Ross IB } \\
(\mathbf{n = 1 1})\end{array}$ & $\begin{array}{c}\text { Ross IC } \\
(\mathbf{n = 2 9})\end{array}$ & KW & p \\
\hline NT- ProBNP (pg/ml) & \multicolumn{6}{|c|}{} \\
\hline $\begin{array}{l}\text {-Median } \\
\text {-Range }\end{array}$ & $\begin{array}{c}1900 \\
530-3800\end{array}$ & $\begin{array}{c}4800 \\
4200-5500\end{array}$ & $\begin{array}{c}6300 \\
5800-10800\end{array}$ & 31.47 & $\begin{array}{c}<0.001 \\
\text { HS }\end{array}$ \\
\hline
\end{tabular}

$\mathrm{KW}=$ Kruskal Wallis test

HS= Highly Significant

The serum level of NT-proBNP showed statistically significant increase in cases of HFrEF compared to cases of HFpEF with $p$ value $<0.05$ (Table 6, Fig. 3). Also, The serum level of
NT-proBNP showed statistically highly significant increase in cases of HFpEF compared to control group with $\mathrm{p}$ value $<0.001$ (Table 7 , Fig. 3). 
Table (6): Comparison between HFpEF and HFrEF regarding the serum level of NT-proBNP

\begin{tabular}{|c|c|c|c|c|}
\hline Variable & $\begin{array}{c}\text { HFpEF } \\
(\mathbf{E F}>\mathbf{5 0 \%})(\mathbf{n}=\mathbf{6})\end{array}$ & $\begin{array}{c}\text { HFrEF } \\
(\mathbf{E F}<\mathbf{5 0 \%})(\mathbf{n}=\mathbf{3 9})\end{array}$ & MW & $\mathbf{p}$ \\
\hline NT- ProBNP $(\mathbf{p g} / \mathbf{m l})$ & $\begin{array}{c}6900 \\
\text { Median }\end{array}$ & $\begin{array}{c}6200 \\
1900-10800\end{array}$ & 59 & $0.049 \mathrm{~S}$ \\
\hline
\end{tabular}

$\mathrm{HFpEF}=$ heart failure with preserved ejection fraction

$\mathrm{S}=$ Significant

$\mathrm{HFrEF}=$ heart failure with reduced ejection fraction

MW = Mann-Whitney test.

Table (7): Comparison between HFpEF and controls regarding the serum level of NT-proBNP

\begin{tabular}{|c|c|c|c|c|}
\hline Variable & $\begin{array}{c}\text { CHFpEF } \\
(\mathbf{E F}>\mathbf{5 0 \%})(\mathbf{n}=\mathbf{6})\end{array}$ & $\begin{array}{c}\text { Control } \\
(\mathbf{n = 1 5})\end{array}$ & MW & $\mathbf{p}$ \\
\hline NT- ProBNP (pg/ml) & $\begin{array}{c}4900 \\
530-6300\end{array}$ & $\begin{array}{c}179 \\
89-1100\end{array}$ & 1.000 & $<0.001$ HS \\
\hline $\begin{array}{l}\text { Median } \\
\text { Range }\end{array}$ &
\end{tabular}

$\mathrm{HFpEF}=$ heart failure with preserved ejection fraction

$\mathrm{HS}=$ highly significant

$\mathrm{HFrEF}=$ heart failure with reduced ejection fraction

MW = Mann-Whitney test.

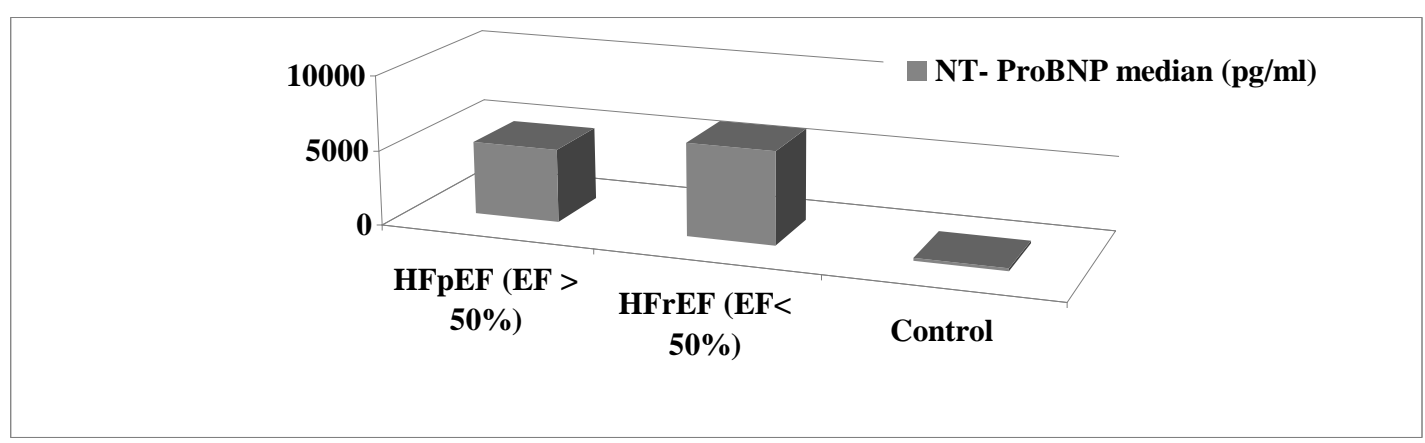

Figure (3): Comparison between cases of HFpEF

and cases of HFrEF regarding the erusm level of NT-p roBNP

There is highly significant statistical positive correlation between serum NT-proBNP and Modified Ross Score in the 45 cases of CHF with $\mathrm{p}$ value <0.001. NT-proBNP showed statistically highly significant positive correlations with LVEDD and LVESD with $p$ value $<0.001$ for each, and highly significant negative correlations with left ventricular $\mathrm{EF}$ and
FS with $\mathrm{p}$ value $<0.001$ for each item, and statistically significant negative correlation with mitral valve E/A ratio with $\mathrm{p}$ value $=0.001$. Serum NT-proBNP showed non statistically significant correlations with age, body weight, length, heart rate, respiratory rate and $\mathrm{CBC}$ parameters in the 45 cases of CHF(Table 8, Fig. 4-8). 
Table (8): Correlation between NT- ProBNP level in patients of CHF and age, body weight, length, vital signs, Modified Ross Score, $\mathrm{CBC}$ and $\mathrm{ECHO}$ findings

\begin{tabular}{|c|c|c|}
\hline Variable & $\begin{array}{c}r \\
(n=45)\end{array}$ & $\begin{array}{c}P \\
(n=45)\end{array}$ \\
\hline Age & -0.017 & $0.913 \mathrm{NS}$ \\
\hline Body weight & -0.056 & $0.714 \mathrm{NS}$ \\
\hline Length & -0.099 & $0.529 \mathrm{NS}$ \\
\hline Heart rate & 0.039 & $0.804 \mathrm{NS}$ \\
\hline Respiratotry rate & -0.05 & $0.746 \mathrm{NS}$ \\
\hline Modified Ross score & 0.848 & $<0.001 \mathrm{HS}$ \\
\hline $\mathrm{Hb}(\mathrm{gm} / \mathrm{dL})$ & -0.02 & $0.898 \mathrm{NS}$ \\
\hline RBCs (x 1000) & 0.097 & $0.524 \mathrm{NS}$ \\
\hline WBCs (x 1000) & -0.052 & $0.733 \mathrm{NS}$ \\
\hline Platelets (x 1000) & -0.040 & $0.792 \mathrm{NS}$ \\
\hline LVEDD (mm) & 0.634 & $<0.001 \mathrm{HS}$ \\
\hline LVESD (mm) & 0.742 & $<0.001 \mathrm{HS}$ \\
\hline $\mathrm{EF} \%$ & -0.634 & $<0.001 \mathrm{HS}$ \\
\hline FS\% & -0.568 & $<0.001 \mathrm{HS}$ \\
\hline E/A ratio & -0.585 & $0.001 \mathrm{HS}$ \\
\hline
\end{tabular}

$\mathrm{NS}=$ non-significant, $\mathrm{HS}=$ highly significant, $\mathrm{HB}=$ Hemoglobin, $\mathrm{RBCs}=$ Red Blood Cells, $\mathrm{WBCs}=$ White Blood Cells, $\mathrm{EF}=$ Ejection fraction, $\mathrm{FS}=$ Fractional shortening, $\mathrm{LVEDD}=$ Left ventricular end diastolic dimensions, $\mathrm{LVESD}=$ Left ventricular end systolic dimensions, E/A ratio= Mitral valve E/A ratio.

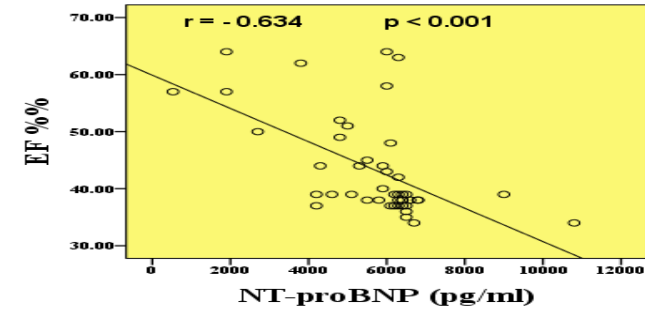

Figure (4): Correlation between NT- ProBNP level and left ventricular EF\%

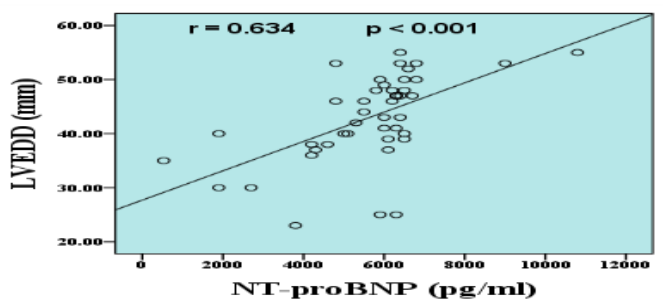

Figure (6): Correlation between NT- ProBNP level and LVEDD

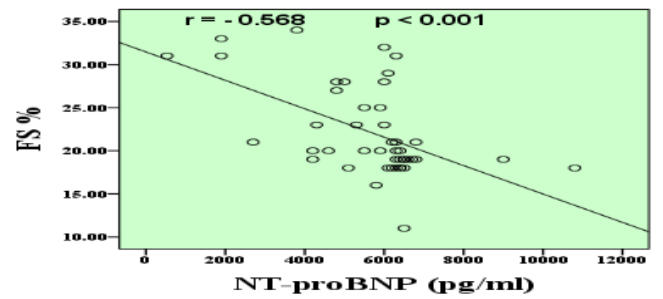

Figure (5): Correlation between NT- ProBNP and left ventricular FS\%

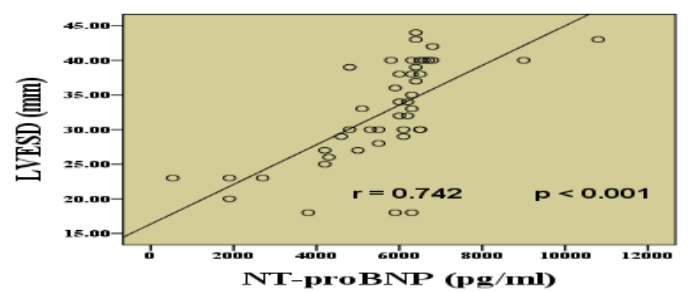

Figure (7): Correlation between NT- ProBNP level and LVESD

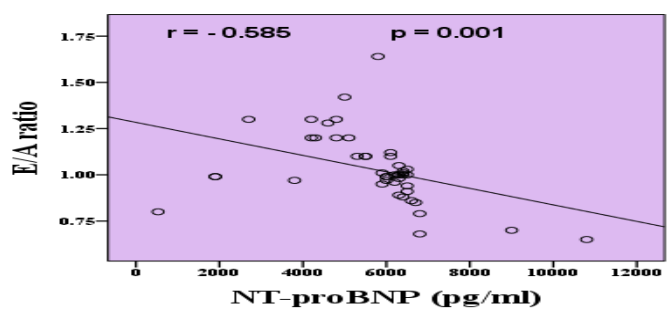

Figure (8): Correlation between NT- ProBNP level and mitral valve E/A ratio 
The best cutoff value of NT-proBNP in diagnosis of CHF was $1500 \mathrm{pg} / \mathrm{ml}$ with $98 \%$ sensitivity and $100 \%$ specificity and the $\mathrm{p}$ value $<0.001$ (Table 9 ).

Table (9): Validity of NT- ProBNP in diagnosis of CHF

\begin{tabular}{|c|c|c|c|c|}
\hline Cutoff & AUC & Sensitivity & Specificity & p-value \\
\hline 1500 & 0.99 & $98 \%$ & $\% 100$ & $<0.001 \mathrm{HS}$ \\
\hline
\end{tabular}

AUC $=$ Area under the curve

HS= Highly Significant

\section{DISCUSSION}

Brain natriuretic peptide (BNP) is one of the cardiac markers for CHF. It correlates with symptoms of CHF and may indicate LV volume and pressure overload in the presence of shunt [11]. The N-terminal fragment of proB-type natriuretic peptide (NT-proBNP) is secreted from cardiac myocytes together with BNP. Both BNP and NT- proBNP have been used to identify the presence and to determine the severity of CHF in children $[12,13]$. Most of the pediatric studies demonstrate an increase in natriuretic peptide levels in proportion to the symptomatic severity and the degree of remodeling in diverse pediatric cardiac diseases [14]. In this study, we hypothesize that changes in NT-proBNP serum levels are associated with changes in echocardiographic indices of LV systolic and diastolic function in children in CHF in cases of DCM, CHD and CHF of non cardiac origin, so we studied whether the rapid bedside determination of NTproBNP level could be used for diagnosis of CHF and to predict the severity.

There was no statistically significant difference between the groups of cases (DCM, CHD and cases of non cardiac origin of CHF in our study regarding the proportion of CHF classes of clinical severity according to modified Ross score. Among whole cases, Ross IA (Mild CHF) represented $11.1 \%$ (5 cases), Ross IB (Moderate CHF) represented $24.4 \%$ (11 cases), and Ross IC (Severe CHF) represented 64.4\% (29 cases).

With respect to the echocardiographic parameters in our study, there was statistically highly significant decrease in EF\% and FS \% (representing systolic dysfunction) in CHF cases of group I (1,2 and 3) as compared with the control group (group II) with $\mathrm{p}$ value <0.001. In addition, there was statistically highly significant increase in LVEDD and LVESD in the patient groups as compared with the control group with $\mathrm{p}$ value $<0.001$. There is statistically significant decrease in E/A ratio (representing diastolic dysfunction) in the CHF cases groups as compared to the control group with $\mathrm{p}$ value $<0.001$. This has agreement with Zoair et al., who studied 20 cases of DCM and 20 healthy controls, they found that there is statistically significant difference between the group DCM cases and the control group regarding $\mathrm{EF} \%$, FS\%, LVEED and LVESD, with $\mathrm{p}$ value of 0.001 for each parameter. The study did not include E/A ratio [15]. Also, Elwan et al. who studied 42 patients (24 ASD and 18 VSD, 11 of them in CHF) and 15 healthy controls found statistically significant difference between cases of CHD (ASD, VSD with and without CHF) and control group regarding LVEED and LVESD [16].

In our patients of CHF, there was a highly statistically significant increase in the level of NT-proBNP in CHF cases in group I (1, 2 and 3) compared to the control group (group II) with $\mathrm{p}$ value $<0.001$. While there is no significant statistical difference among the three groups of cases (I-1, I-2 and I-3) regarding NT-proBNP level. There is statistically significant difference between the grades of clinical severity in CHF cases classified according to Modified Ross Score (RossIA, Ross IB and Ross IC) regarding the level of NTproBNP with $p$ value $<0.001$. Koura et al. (17) supported our study as they had a cross sectional (comparative) study where 30 children divided into 11 cases of DCM and 19 cases of LRS (left to right shunt). They conclude that the NTProBNP level is elevated in both LRS and DCM in pediatric age. This elevation is more remarkable with heart failure and increased pulmonary artery pressure (PAP) in both diseased groups. Also, Narin et al. agreed with our study, as they found a statistically significant difference between NTProBNP levels in each Ross clinical group not only before treatment but also on assessment on the 7th day of treatment in the patient group ( $<$ 0.001) [18]. 
In our study, there was statistically highly significant increase in the level of serum NTproBNP in cases of $\mathrm{CHFpEF}$ in comparison to control group with $\mathrm{p}$ value $<0.001$. Also, there was statistically significant decrease in the level of serum NT-proBNP in cases of HFpEF in comparison to cases of $\mathrm{HFrEF}$ with $\mathrm{p}$ value $<0.05$. This has agreement with Masutani et al. who studied 18 pediatric patients with $\mathrm{HFpEF}$ and 22 patients with HFrEF; as they found plasma BNP levels were elevated in both CHF groups, but to a significantly smaller degree in $\mathrm{HFpEF}$ than in systolic heart failure (SHF) patients [19].

Our results showed there is no correlation between serum NT-proBNP and patients' age, body weight, length, heart rate, respiratory rate and CBC parameters (HB, RBCs, WBCs and platelets) in group I (45 CHF patients). But we found statistically highly significant positive correlation between serum NT-proBNP and the class of clinical severity according to Modified Ross Score with $\mathrm{p}$ value $<0.001$. Regarding echocardiographic parameters NT-proBNP showed highly significant positive correlation with LVEDD and LVESD, and highly significant negative correlation with ejection fraction and fractional shortening with $\mathrm{p}$ value $<0.001$. Also, NT-proBNP showed significant negative correlation with mitral valve E/A ratio with $p$ value $=0.001$. Elwan et al. supported our study as they found significant positive correlations between NT-proBNP concentration with LVEDD, LVESD, systolic pulmonary artery pressure (SPAP), and shunt size, and there was significant negative correlation with EF and FS, in cases of CHD (ASD, VSD with and without $\mathrm{CHF}$ ), but in our study we did not examine SPAP and their study did not include mitral valve E/A ratio [16].

The results of our study showed that, using a cutoff point of NT-proBNP as $1500 \mathrm{pg} / \mathrm{ml}$, the sensitivity of NT-proBNP as a diagnostic biomarker in children with CHF was $98 \%$ and the specificity was $100 \%$. This has agreement with Zoair et al. who used a cutoff point of NT-proBNP as 1500 $\mathrm{pg} / \mathrm{ml}$ as a diagnostic biomarker in children with DCM, the sensitivity was $85 \%$ and the specificity was $100 \%$ [15]. However, Rusconi et al. who studied CHF in 36 pediatric patients with DCMfound that NT-proBNP level above $1000 \mathrm{pg} / \mathrm{ml}$ clearly identified the sickest patients. NT-proBNP levels between 450 and $1000 \mathrm{pg} / \mathrm{ml}$ did not distinguish between symptomatic and asymptomatic patients [20]. With a marked difference from our study, Narin et al. used the NT-proBNP cut off value of $174.3 \mathrm{pg} / \mathrm{ml}$ to distinguish healthy children from the patients with left ventricular systolic dysfunction caused by cardiomyopathy [18], this may be due to the difference in properties of the kit used.

NT-ProBNP level is significantly elevated in CHF with different causes ( DCM, CHD and non cardiac causes of CHF) and in cases of HFpEF in pediatric age. So, we recommend the use of NTProBNP as a routine marker for diagnosing suspected patients with symptoms and signs suggesting $\mathrm{CHF}$ for rapid evaluation of cardiac functions, especially in absence of reachable echocardiographic examination.

Funding: None.

Conflicts of interest: None.

Ethical approval:Approved.

\section{REFERENCES}

1- Behrman RE, Kliegman RM, Jenson HB. Nelson textbook of pediatrics Saunders. Philadelphia, PA. 2004

2- Yancy CW, Jessup M, Bozkurt B, Butler J, Casey DE, Drazner MH et al. 2013 ACCF/ AHA guideline for the management of heart failure: a report of the American College of Cardiology Foundation/ American Heart Association Task Force on Practice Guidelines. J Am Coll Cardiol 2013; 62: e147-239.

3- McMurray JJ, Stewart S. Epidemiology, aetiology, and prognosis of heart failure. Heart. 2000; 83(5):596-602.

4- Bondi P, Jaiyesimi F. Heart Failure in an emergency room setting. Nig J Paediatr. 1990; 17:37-41.

5- 5-Adekanmbi A, Ogunlesi T, Olowu A, Fetuga M. Current trends in the prevalence and aetiology of childhood congestive cardiac failure in Sagamu. Journal of Tropical Pediatrics. 2007; 53(2):103-6.

6- Oyedeji O, Oluwayemi I, Oyedeji A, Okeniyi J, Fadero F. Heart failure in Nigerian children. Cardiology. 2010;5(3-4):18-22.

7- Kantor PF, Andelfinger G, Dancea A, Khairy P. Heart failure in congenital heart disease. Can $J$ Cardiol; 2013;29:753-4.

8- Rossano JW, Kim JJ, Decker JA, Price JF, Zafar F, Graves DE et al. Prevalence, morbidity, and mortality of heart failure-related hospitalizations in children in the United States: a populationbased study. J Card Fail; 2012;18:459-70.

9- Maries L, Manitiu I. Diagnostic and prognostic values of B-type natriureticpeptides (BNP) and $\mathrm{N}$-terminal fragment brain natriuretic peptides (NT-pro-BNP). Cardiovasc J Afr; 2013 Oct; 24(7): 286-289. 
10- Lin CW, Tang W, Wen F, Chen JJ, Zeng XL, Chen ZG. Diagnostic Accuracy of NT-ProBNP for Heart Failure with Sepsis in Patients Younger than 18 Years. Harold S. Bernstein, Editor. PLoS One \{Internet\}. 2016 Jan 26 \{cited 2016 May 15\}; 11(1): e0147930. Available from: http:// journals.plos.org/plosone/article?id $=\quad 10.1371 /$ journal.pone.0147930.

11- Nir A, Nasser N. Clinical value of NT-ProBNP and BNP in pediatric cardiology. J Card Fail; 2005; 11:76-80.

12- 12-- Mangat J, Carter C, Riley G, Foo Y, Burch M. The clinical utility of brain natriuretic peptide in paediatric left ventricular failure. Eur J Heart Fail; 2009; 11:48-52.

13- 13-Geiger R, Hammerer-Lercher A, Url C, Schweigmann U, Puschendorf B, Sommer R et al. NT-proBNP concentrations indicate cardiac disease in pediatric patients. Int J Cardiol; 2007; 123:63-65.

14- 14-Abassi Z, Karram T, Ellaham S, Winaver J, Hoffman A. Implications of the natriuretic peptide system in the pathogenesis of heart failure: diagnostic and therapeutic importance. Pharmacol Ther; 2004; 102:223-241.

15- 15-Zoair AM, Mawlana WH, El-Bendary AS, Nada EA. Serum levels of amino terminal of probrain natriuretic peptide (NT-ProBNP) as a diagnostic and prognostic biomarker in children with dilated cardiomyopathy. Tanta Medical Journal 2014, 42(2):53-57.

16- Elwan SA, Belal TH, Abd El-Aty RE And Salem MA. Diagnostic Value of N-Terminal Pro-Brain Natriuretic Peptide Level in Pediatric Patients with Atrial or Ventricular Septal Defect. Med. J. Cairo Univ. 2015; 83(2): 279-283. www.medicaljournalofcairouniversity.net.

17- Koura HM, Abdalla NM, Ibrahim MH, Abo Hashish MM1, Zaki SM. NT-proBNP in Children With Left to Right Shunt and Dilated Cardiomyopathy. Iran J Pediatr. In Press In Press):e4485. doi: 10.5812/ijp.4485. http://ijp. tums.pub/en/latest.html.

18- Narin N, Hekimoglu B, Baykan A, Uzum K. The role of $\mathrm{N}$-terminal proBNP in the clinic scoring of heart failure due to dilated cardiomyopathy in children. Clin Lab; 2014;60(4):563-70.

19- 19-Masutani S, Saiki H, Kurishima C, Ishido H, Tamura M, Senzaki H. Heart Failure With Preserved Ejection Fraction in Children Hormonal Imbalance Between Aldosterone and Brain Natriuretic Peptide. Circulation Journal; 2013; 77 (9): 2375 - 2382.

20- Rusconi PG, Ludwig DA, Ratnasamy C, Mas R, Harmon WG, Colan SD et al. Serial Measurements of Serum NT-proBNP as Markers of Left Ventricular Systolic Function and Remodeling in Children with Heart Failure. Am Heart J; 2010 October ; 160(4): 776-783. doi:10.1016/j.ahj.2010.07.012. 